\title{
Systematization and analysis of approaches to assessing the competitiveness of business entities
}

\author{
Vadim Krivorotov ${ }^{1}$, Aleksandr Tarasenko ${ }^{2}$, Evgeniy Tikhanov ${ }^{1}$, Petr Chepur ${ }^{2}$, and Alesya \\ Gruchenkova ${ }^{3, *}$ \\ ${ }^{1}$ Ural Federal University named after the first President of Russia B. N. Yeltsin, 620002 Mira Street \\ 19, Russia \\ ${ }^{2}$ Industrial University of Tyumen, 625000 Volodarskogo Street 38, Russia \\ ${ }^{3}$ Surgut Oil and Gas Institute, 628405 Entuziastov Street 38, Russia
}

\begin{abstract}
Assessment of competitiveness is an objective need of every business entity seeking to maintain or improve their own competitive position and make informed management decisions. The authors propose to classify the diversity of methods of assessment of the competitiveness of the enterprise through three main approaches: graphic, factor and value. In order to identify the advantages and disadvantages of each of the approaches described by the authors, the content of the main methods used in the study was analyzed. It is concluded that there is no universal tool for assessing the competitiveness of the enterprise, which is due to, on the one hand, the limited reliability and low estimates obtained by using matrix and product methods, and on the other hand, the complexity and cost of the estimates using existing multivariate models.
\end{abstract}

\section{Introduction}

In the situation of sharp competition between market participants, assessment of competitiveness is an objective need of each business entity seeking to maintain or improve its own competitive positions and make informed management decisions [1]. Assessment of the enterprise's competitiveness consists in determining and subsequently analyzing a set of key performance indicators of a business entity to identify the main competitive advantages of the organization, determine its current competitive position in the market and develop a set of effective solutions aimed at ensuring the further development of the enterprise [2, 3].

At present, both in domestic and in world practice, there is no single generally accepted approach to assessing the competitiveness of business entities [4-8]. In many ways, this circumstance is explained by the diversity of views of researchers on the essence of the notion of enterprise competitiveness. At the same time, it is necessary to take into account the presence of a huge number of factors and components of the company competitiveness that must be considered to obtain an objective assessment. In view of the foregoing, we have to state that in the absence of universal and at the same time sound criteria for assessing the

*Corresponding author: alesya2010-11@yandex.ru 
competitiveness of enterprises to determine their level of competitiveness, economists use a variety of different methods, all of which are proposed to be classified into three main approaches: graphic, factor and value [9-13] (Figure 1).

\section{Methods}

A graphic approach to assessing the competitiveness of an enterprise makes it possible to obtain a visual representation of the competitive position of an enterprise in the market in question compared to key competitors using various graphic tools. In the framework of the graphic approach, the authors propose to distinguish two groups of methods: matrix methods and a method of compiling a polygon of competitiveness [14].

A factor approach involves determining a set of and obtaining a quantitative assessment of the main factors of the enterprise's competitiveness in comparison with its competitors. Among the methods identified within this approach are product, operational and integrated methods.

A value approach to assessing the competitiveness of companies is based on the fact that the value of an enterprise can be regarded as the main criterion for the success and effectiveness of functioning of a business entity under market conditions, since it is the final resultant criterion for assessing the entire set of external and internal competitive advantages of the enterprise. Within the framework of the third approach, competitiveness of companies is determined using traditional valuation techniques.

To identify the advantages and disadvantages of each of the identified approaches to assessing the competitiveness of an enterprise, let us turn to the analysis of the substantive component of the main methods used by researchers.

\section{Results and discussion}

\subsection{Graphic approach}

1. Matrix methods (Figure 1). This group of methods for assessing the competitiveness of business entities owes its name to a form used to display the results of analysis of competitive positions of the enterprise in the form of matrices of different dimensions. On the horizontal axis of the matrix most economists plot the value of the indicator characterizing the company's market position, and vertically - the value of the indicator reflecting the degree of attractiveness of this market [15]. In the framework of matrix methods, enterprises are considered as a set of business units that form a single product portfolio. Hence, we should note a significant bias of matrix methods in the direction of marketing evaluation of the business entity.

The most famous and widely used are the matrix models proposed by American consulting companies: the Boston Consulting Group and McKinsey, and later by Shell and the economist I. Ansoff.

All matrix methods are similar in their relative simplicity and clarity of the assessment results. In addition, construction of matrix models gives a fairly objective idea of the balance and competitiveness of the enterprise's product portfolio and allows outlining strategic directions for improving the company's competitive position. At the same time, many researchers point to the inadmissibility of treating the enterprise as a set of business units, since in this case, when evaluating competitiveness, a number of factors are not taken into account, which significantly reduces the reliability of the results obtained.

2. A method of constructing a competitiveness polygon (Figure 2). This method is based on assessment of the competitive positions of the enterprise and its main competitors in key 
components of business activity, represented in the form of vectors. The result of the assessment is the construction of polygons of competitiveness of a business entity and its competitors, which are a graphic combination of estimates for each of the vectors.

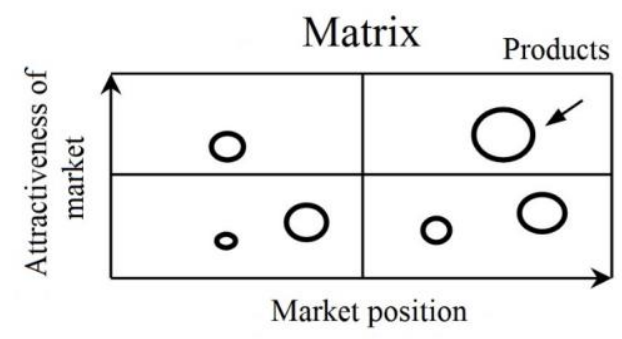

Fig. 1. General view of the competitiveness evaluation model of the enterprise at the matrix method.

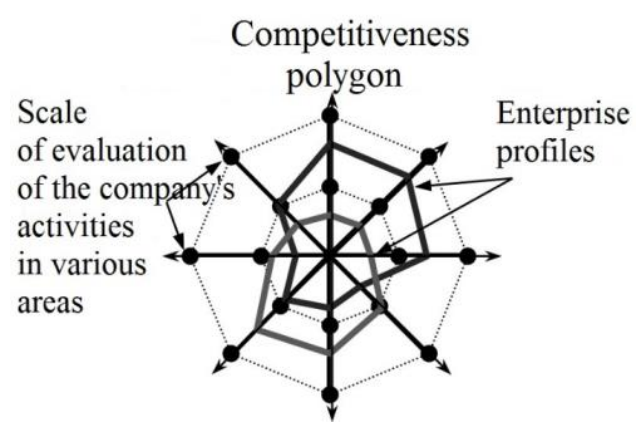

Fig. 2. General view of the competitiveness evaluation model of the enterprise at the method of constructing a competitiveness polygon.

The main advantage of the method is clarity of the assessment results. The analysis of the obtained polygon allows quickly assessing the competitive position of the researched business entity, determining the key factors of the enterprise's competitiveness and developing targeted measures aimed at maintaining the existing competitive advantages and developing less successful lines of business compared with competitors.

Integration of the mathematical apparatus into the method under consideration which makes it possible to obtain a quantitative assessment of the level of competitiveness of an enterprise significantly increases the practical value of the results obtained. The main drawback of the method is the widespread use of scoring expert assessments of the investigated characteristics of the enterprise's activity, which generates excessive subjectivity in the process of analysis.

\subsection{Factor approach}

1. Product methods. The authors of this group of methods proceed from the fact that the enterprise's ability to successfully compete with other market participants is determined by the competitiveness of its products. Economists draw attention to the fact that business practice in most cases confirms their position, and argue that the more competitive the product, the higher the competitiveness of the business entity and vice versa. The main criterion for assessing the competitiveness of products is finding the ratio of the price and quality of goods. In the most general form within the product method, the company's 
competitiveness indicator is defined as the arithmetic mean of the weighted indicators of competitiveness of each type of product produced by the enterprise [16]:

$$
K=\sum K_{\text {prod.,i }} \times D_{\text {prod.i }}
$$

where $\mathrm{K}_{\text {prod., }}$ - volume of production;

$\mathrm{D}_{\text {prod.,i }}$ - specific weight of products in total sales.

Analysis of existing product methods allows us to state that their main advantage is a comprehensive assessment of one of the most important components of the competitiveness of a business entity - the competitiveness of its products.

The use of product methods makes it possible to obtain a fairly objective quantitative assessment of the attractiveness of the company's product portfolio for consumers, as well as to analyze the factors that affect the change in the dynamics of demand for the enterprise's products.

However, it should be noted that assessment of the company's competitiveness based on product methods is rather limited, since it does not allow getting an idea of the level of efficiency of the economic activity, and does not take into account the indicators characterizing the competitive potential of the enterprise.

2. Operational methods. This group of methods is based on the basic provisions of the theory of effective competition, according to which the level of competitiveness of a business entity is determined by the degree of effectiveness of the organization of activities of individual units of the enterprise. At the same time, the efficiency of functioning of each of the enterprise's services directly depends on the productivity of the use of limited resources and the effectiveness of performing certain functional operations.

As in the case of product methods, the integral indicator of the competitiveness of a business entity is most often calculated by the formula of the average arithmetic weighted:

$$
K=\sum K_{\text {unit. }, i} \times B_{\text {unit.i }}
$$

where $\mathrm{K}_{\mathrm{unit.,i}}$ - indicators of competitiveness of the enterprise functional units; $\mathrm{B}_{\text {unit.,i }}$ - the importance of functional units for enterprise activities.

At the same time, individual efficiency factors of individual operations performed by the company's units, obtained by comparing the performance indicators of the enterprise under investigation with similar performance indicators of competitors or reference values, are multiplied by the corresponding weighted factors, usually determined by expertise.

The main advantages of operational methods are the coverage of a wide range of key performance indicators of the business entity, the use of real reporting data in the process of calculating the competitiveness of the enterprise, which allows obtaining a fairly accurate and objective assessment of the company's competitiveness. The main drawback of operational methods is the need to collect a large array of raw data comprehensively characterizing the activities of the enterprise and its competitors [17]. This fact turns the process of collecting and processing necessary information into an extremely laborious and financially costly task, which greatly reduces the practical applicability of the group of methods under consideration.

3. Comprehensive methods. A feature of these methods is assessment of the competitiveness of a business entity based on a comprehensive analysis of indicators of its current competitiveness and competitive potential $[18,19]$.

Many researchers consider the company's current competitiveness as the competitiveness of its products and perform an assessment using models offered by the authors of product methods. A competitive potential of the organization mentioned by the authors is often determined by assessing the effectiveness of the use of various resources of the enterprise by 
analogy with product methods. The integral indicator of the enterprise's competitiveness in most complex methods, as well as in other methods, identified within the framework of the factor approach, is calculated by the formula of the average arithmetic weighted:

$$
K=K_{\text {actual }} \times B_{1}+K_{\text {potent. }} \times B_{2} \sum K_{\text {unit. }, i} \times B_{\text {unit. } i}
$$

where $\mathrm{K}_{\mathrm{actual}}$ - actual competitiveness of the enterprise;

$\mathrm{K}_{\text {potent. }}$ - potential competitiveness of the enterprise.

According to the authors, the main advantage of comprehensive methods is the desire of their authors to take into account, based on a combination of indicators of the current competitiveness and competitive potential, not only the level of competitiveness achieved by the business entity, but also the prospects for its growth in the future, which is quite valuable from a practical point of view. At the same time, analysis of the proposed comprehensive methods makes it possible to note that the mathematical apparatus used to assess the current and potential competitiveness of an enterprise, as well as the composition of the indicators being evaluated, is a legacy of the previously reviewed product and operational methods.

This gives grounds to state that comprehensive methods, based on the apparatus of other factor methods, reproduce their main shortcomings. On the one hand, comprehensive methods adopt the laboriousness of operational methods, on the other hand, the methodological inconsistency of assessing the competitiveness of products based on product methods.

\subsection{Value approach}

Today, many researchers agree that the market value of the company is the main indicator of its development, and propose considering the value of business as the most complex characteristic of the competitiveness of the business entity. The indicator of the market value of the enterprise, being the central object of management in most of large companies, simultaneously absorbs assessment of the efficiency of business activity, quality of management, financial stability and business growth prospects. The undoubted advantage of assessing the competitiveness of an enterprise on the basis of value approach methods is analysis of the entire set of key characteristics of the business entity.

However, the process of gathering the necessary information about the operation of the enterprise and its competitors is too time consuming, and therefore the use of methods for assessing the value of business to assess the competitiveness of the company is quite difficult, and sometimes almost impossible.

Summarizing the analysis of approaches to assessing the competitiveness of business entities, it should be noted that to date, none of the assessment methods considered by the authors of this work have found wide practical application and cannot be recognized as a universal analytical tool. In this connection, in the economic environment, a relevant task is developing a universal method of assessing the competitiveness of enterprises that provides a comprehensive and, at the same time, objective assessment of the competitiveness of a business entity [6], and has a wide range of practical applications.

\section{Conclusions}

As a result of the work, existing methods of assessing the competitiveness of enterprises were systematized within the framework of three approaches: graphic, factor and value. The essence of six basic methods of assessing the competitiveness of business entities is analyzed, a general view of the valuation model is proposed using each of the methods. Key advantages 
and disadvantages of the methods for assessing the competitiveness of companies are identified. The relevance of developing a universally recognized method for assessing the competitiveness of enterprises is substantiated.

\section{References}

1. L.G. Iogman, M.A. Gusakov, The Region's Econ. 4, 85-94 (2007)

2. V.V. Krivirotov, A.V. Kalina, E.A. Tikhanov, S.E. Erypalov, Vestnik of the Ural Fed. Univ. 2, 61-74 (2014)

3. V.V. Krivirotov, Metodologiya formirovaniya mekhanizma upravleniya konkurentosposobnost'yu predpriyatiya (Ural State Technical University, Yekaterinburg, 2007)

4. V.V. Krivirotov, A.V. Kalina, T.V Matveeva, A.Yu. Bayranshin, Povyshenie konkurentosposobnosti sovremennykh rossiyskikh territorial'no-proizvodstvennykh kompleksov (Ural State Technical University, Yekaterinburg, 2013)

5. V.V. Krivirotov, A.V. Kalina, V.D. Tretyakov, E.A. Tikhanov, K.E. Parfenov, Vestnik of the Ural Fed. Univ. 4, 61-76 (2013)

6. V.L. Belousov, Analiz konkurentosposobnosti firmy (Marketing in Russia and abroad, Moscow, 2007)

7. K.G. Borodin, Konkurentosposobnost'v rynochnoy ekonomike (Teis, Moscow, 2006)

8. V.A. Bykov, T.G. Filosofa, Konkurentsiya. Innovatsii. Konkurentosposobnost' (Uniti, Moscow, 2008)

9. E.I. Mazilkina, G.G. Panichkina, Upravlenie konkurentosposobnost'yu (Omega-L, Moscow, 2007)

10. V.V. Krivirotov, I.V. Ershova, I.S. Belik, Konkurentosposobnost' sotsial'noekonomicheskikh sistem: vyzovy novogo vremeni (Economika, Moscow, 2014)

11. A.L. Denisova, N.V. Ylyakhin, Upravlenie konkurentosposobnost'yu promyshlennogo predpriyatiya: aspekty kachestva (Tambov state technical University, Tambov, 2006)

12. T.Yu. Ivanova, V.I. Prikhodko, Teoriya organizatsii (KnoRus, Moscow, 2010)

13. V.P. Zotov, Kompleksnyy ekonomicheskiy analiz khozyaystvennoy deyatel'nosti (Kemerovo, 2009)

14. A.A. Kuzubov, Fundam. Res. 12(4), 801-805 (2015)

15. A.V. Postrelova, M.C. Markin, Young Sci. 6, 398-402 (2013)

16. A.A. Vornov, Stand. and Qual. 5, 59-65 (2012)

17. I.B. Gurkov, Innovatsionnoe razvitie $i$ konkurentosposobnost': ocherki razvitiya rossiyskikh predpriyatiy (Teis, Moscow, 2012)

18. A. Chaplina, I. Voytsekhovskaya, Probl. of manag. theor. and pract. 3, 108-113 (2012)

19. B.M. Enis, K.T. Koks, M.P. Mokva, Klassika marketinga (Piter, Saint-Petersburg, 2012)

20. A.A. Anfinogentova, M.N. Dudin, N.V. Lyasnikov, O.D. Protsenko, Economy of Region 14, 638-650 (2018), doi:10.17059/2018-2-24 